\title{
Not Made with Natural Rubber Latex
}

National Cancer Institute

\section{Source}

National Cancer Institute. Not Made with Natural Rubber Latex. NCI Thesaurus. Code C106038.

The composition of the materials of an item do not contain natural rubber latex. 